\title{
Energy Storage and Thermal Control System Design Status
}

Stephen N. Simons

Lewis Research Center

Cleveland, Ohio

Bryan C. Willhoite

Rocketdyne Division

Canoga Park, California

and

Gert van Ommering

Ford Aerospace

Palo Alto, California

Prepared for the

24th Intersociety Energy Conversion Engineering Conference cosponsored by the IEEE, AIAA, ANS, ASME, SAE, ACS, and AIChE Washington, D.C., August 6-11, 1989 


\section{ENERGY STORAGE AND TH' 'RMAL CONTROL SYSTEM DESIGN STATUS}

\author{
Stephen N. Simons \\ NASA Lewis Research Center \\ Cleveland, Ohio 44135
}

\author{
Bryan C. Willhoite \\ Rocketdyne Division \\ Canoga Park, Calif. 91303
}

\author{
Gert van Ommering \\ Ford Aerospace \\ Palo Alto, Cálif. 94303
}

\begin{abstract}
The Space Station Freedom electric power system (EPS) will initially rely on photovoltaics for power generation and $\mathrm{Ni} / \mathrm{H} 2$ batteries for electrical energy storage. This paper discusses the current design for and the development status of two major subsystems in the PV Power Module, namely the energy storage subsystem comprised of high capacity $\mathrm{Ni} / \mathrm{H} 2$ batteries and the single phase thermal control system that rejects the excess heat generated by the batteries and other components associated with power generation and storage.
\end{abstract}

\section{BACKGROUND}

NASA has designated Work Package Four to be responsible for the space station Freedom electric power system. The EPS consists of power generation via photovoltaic and solar dynamic sources and a distributed power management and distribution system. Both the electrical energy storage system and the thermal control system discussed in this paper are part of the photovoltaic power module flight element. The PV Power Module work is managed by NASA's Lewis Research Center through Rocketdyne as the prime contractor; Ford Aerospace provides the energy storage subsystem.

A Photovoltaic (PV) power module, shown in Figure 1, includes a photovoltaic (PV) array and an integrated equipment assembly (IEA). The IEA contains the dc subsyctem equipment, dc/ac inverters, ac distribution equipment, thermal control equipment, and the redundant photovoltaic controllers (PVC). Equipment on the IEA is modularized and enclosed in "stancard" orbital replacement units (ORUs). This concept will allow easy removal and replacement of wornout equipment without disturbing the other equipment on the IEA. The ORU enclosures will also have a quick-release mechanism, which may be actuated by either a telerobotic effector or an extravenicular activity (EVA) crewman.
Each PV module will be capable of providing an orbital average of $18.75 \mathrm{~kW}$ of ac power, including a peak power capability of $25 \mathrm{~kW}$, to the manned core payloads, crew systems, and housekeeping systems. Four PV Modules will be used for the initial space station configuration.

\section{PV MODULE ARCHITECTURE}

A top-level block diagram of a PV module dc power subsystem is shown in Figure 2 . The subsystem consists of two PV array wings, five nickel-hydrogen batteries, battery charge/discharge equipment, and dc powerswitching equipment. During the sunlight portion of the orbit, the PV array wings generate and deliver 160 vdc regulated power to the $\mathrm{dc} / \mathrm{ac}$ inverters and the batteries for recharge. ' Regulation is performed by a sequential shunt unit (SSU) attached to each array. Photovoltaic array pointing is accomplished by alpha and beta gimbals. The dc/ac inverter(s) may receive an orbital average $22.7 \mathrm{kw}$. The two inverters may operate in parallel or only one inverter may operate while the other is in a standby mode. The batteries may receive an average $21.13 \mathrm{kw}$ during the sunlight portion of the orbit. Effective charge time during the sunlight period is $50.92 \mathrm{~min}$. Each battery has a battery charge/discharge unit (BCDU), which converts the 160 vdc bus voltage to the battery charge voltage of 115 to $145 \mathrm{Vdc}$.

\section{ENERGY STORAGE SYSTEM}

\section{Overview}

Each of the 20 space station Freedom batteries consists of three seriesconnected ORUs containing thirty 81-Ahr $\mathrm{Ni} / \mathrm{H} 2$ cells specifically designed for low earth orbit (LEO) operation. The battery ORU, shown in Figure 3 , uses a standard ORU enclosure to hold a battery assembly. The standard enclosure transports heat from the assembly baseplate to the PV Module thermal bus, provides electrical connections, and gives structural support. Table 1 gives an overview of battery ORU design and performance parameters. 
Electrical Desion and sizing

The maximum battery DOD is specified at 35 for normal eclipse operation and 80 8 for contingency operations. At the required power levels, the eclipse cycle DOD limit drives the total design energy content requicement. The $90-c e l l$ battery design was selected based on the nomina? bus volthife of $160 \mathrm{~V}$, an appropriate charge voltage conveision margin, and constraints of stanciard ORU enciosure sizes. The 81-Ah capacity was selected based on the need for a reasonible level of modularity in each PV Module, plating power compatibility, anci maturity of hardware designs at this capacity level.

Electrical circuit design of the battery assemblies includes a bypass diode network for each cell, cell voltage sensor wiring, several cell pressure sensing (strain gage) circuits, and heater/reconditioning circuits and relays. Insulation design ircludes double insulation between the cells and the anodized battery structure and complete conformal coating.

\section{Therma and Mechanical Desig.}

The thermal and mechanical designs are derived from the Ford Aerospace 83-Ah hattery assembly developed for the Japanese superbird (SCS.1) satelitite program. The space station vattery package contains a tix5 rectangular matrix of cell/sleeve subassemblies on nominal 4,5-inch centers. These subassemblies are structuraliy interconnected with light-weight brace structures and a thin baseplate.

The battery assembly mounts to an equipment plate in the ORU enclosure. The enclosure is mounted to the IEA cold plate via a locating and attachment mechanism operated via a single drive with an interface compatible with robotic or EVA tools. Ihis single-action installation of an ORU also mates electrical connectors and establishes thermal interface contact.

The thermal design of the battery assembiy and ORU enclosure will be optimized to maintain proper cell femperatures given the Thermal Control system coolant loop temperature range and practical design constraints for the battery assembly and ORU thermal path elements. In the baseline design, the assembly rejects heat to the internal ORU equipment plate which contains heat pipes that transport heat to a thermal interface pad at the ORU mounting interface. A similar thermal pad in the IEA utility plate is in contact with the TCS loop within the IEA. The overall thermal control objective is to maintain $5 \pm 5^{\circ} \mathrm{C}$ during normal operations and $5-5+15^{\circ} \mathrm{C}$ during off-normal operations, consistent with meeting battery life performance: goals.
Inst rumentation

Each battery ORU contains provisions for individual cell voltage monitoring, pressure measurement via a strain gage bridge, and several thermistors providing control and data temperature signals Signal conditioning will be done tor each group of three ORUs in the associated BCDU. A heater/load circuit with relays in each battery assembly is controlled by BCDU commands and Berves to eupport oft-line hattery discharge as wel: $a_{i}$ heating in sustained low dissipation or aon-installed modes.

\section{Reliability and Life}

High battery reliability is ensured by the capability to toierate short-circuit and open-circuit cell failures. Shorted failure is accommodated by the wide $B C D U$ input voltage capability. Open-circuit failures are accommodated with individualcell bypass diode networks, used in view of the demanding application even though such failures have been absent in on-orbit operation exceeding $28 \mathrm{million}$ cell hours and 6 years of calendar time. Life performance is discussed below under battery cell desigr.

\section{CELL DESIGN}

A cell design optimized for l.EU life performance is a critical factor in mission success. The cel] configuration and component design features represent an integration of technology developed by Ford Aerospace, NASA LeRC, INTELSAT, and the Air Force. The details of configuration and component design implementation will vary with cell marufacturer. Major specified features are a 3.5 inch cell diameter and maximum weight and length of $4.74 \mathrm{lb}$ and 13.5 inches, respectively. The maximum expected operating pressure (MEOP) will be i000 psia and the design burst to MEc: ratio is $3: 1$.

\section{Life Capability}

Battery life capability at 358 DOD is expected to be at least 5 years $(28,000$ cycles). The mean cell life must be considerably higher to ensure a 5-year useful life at the battery level, depending on wear-out distribution. For a Weibull distribution with a 45,000-cycle mean cell life and a beta (shape factor) of 12, the 5-year battery probability of succes!; is 0.99977 . A cell cycle life of 45,000 appears quite feasible at 35 DOD based on cell life and development tests now being conducted in various laboratories.

Figure 4 summarizes projected cycle life capability as a function of DOD based on analysis of available life test data for current-technology celis. The hatched area represents the performance area that cell development for Space station Freedom wil? penetrate as far as cost-effectiveiy possitie. 
Development Approach

Major subjects for cell development are optimization of nickel electrode sinter structure as well as loading and composition of active materiais in nicke] electrodes, low concentration ( 268 by weight.) $\mathrm{KOH}$ electrolyte, enhanced control and uniformity of component manufacturing processes and parameters, and validation of pressure vessel design for the manned, high-cycle life application. To minimize risk, two cell manufacturers will perform the development phase of the program. The selected companies are whittaker-Yardney power systems, Pawcatuck, CT and Gates Energy Producte, Aerospace Battery Division, Gainesville, FL. One of these will be selected to complete qualification and produce the flight cells

\section{Development status}

The focus of early ued development activity is evaluation of design and process alternatives at the component level. Characterization and refinement of existing processes is essential to providing the level of control required for meaningful component design and performance optimization, as well as ultimate successful, repeatable production of the preferred design. As optimization progresses, testing will move from the component level to boilerplate laboratory cells to flight-configuration engineering ceils. Life tests will be conducted at various stages of development and levels of assembly, culminating in life certificatic: based on qualification battery life test:

Pressure vessel design and verification is also receiving early attention. This effort focuses on assessment of the hydrogen environment embrittlement (HEE) behavior of the Inconel 718 material used for the battery celI pressure vessels. While all $\mathrm{Ni} / \mathrm{H} 2$ battery cells over the last 13 years have used this material witholt evidence of HEE problems, a fundamental susceptibility of Inconel 718 to HEE has been established under highpurity hydrogen conditions. The absence of HEE problems in $\mathrm{Ni} / \mathrm{H} 2$ cells is thought to derive from the qualitatively known inhibiting effect of the internal cell environment, containing water vapor and low levels of oxygen, and the moderate pressure level compared to those at which HEE is typically evaluated. The space station Freedom battery program is expected to implement a proposed effort to assess material properties over a range of representative cell environments. A $\mathrm{f}$ inal pressure vessel design will be derived based on verification of these properties in the worst-case environment, fracture mechanics analyses, and non-destructive evaiuation capabilities.

\section{BATTERI OPERATION}

Regulation of battery discharge power is performed by dedicated battery charge/discharge units (BCDU). The BCDU also conditions array bus power for battery charging. Major sulelements of the BCDU are the charge power converter (CPC), the discharge power converter (DPC), battery fault isoletor (EI), control power, remote bus isolator (RBI), and a battery monitor interface module. The DPC boosts the nominal $113 \mathrm{~V}$ battery voltage to about $160 \mathrm{~V}$ and provide regulated current for controlled recharge and charge maintenance. The FI is a fast-acting solid state switch designed to limit and interrupt battery current under fault conditions.

\section{Discharge Management}

The battery system in each module will potentially operate with batteries of different ages, health conditions and possibly using celis from different manufacturers, connected to a common bus. In order to maximize system performance and cost effectiveness over time, control of the relative current share is provided through a combination of BCDU and PVC functions. In this approach, one of the active BCDU's performs the voltage regulation function and provides an analog control signal proportional to its output current. The other BCDUs, as slaves, are in a current regulation mode in which they provide a current proportional to this control signal and a share factor commanded by the PVC.

\section{Charge Management}

Individual charge management of batteries in unequal conditions on the same bus maximizes their life and performance by avoiding excessive charge return and overcharge rates. The BCDUs and PVC perform this task by PVC-based coulometry on discharge, followed by metering recharge capacity according to charge/discharge ratios that can be individualized and periodically adjusted to the battery condition. The PVC integrates charge return because charge rates will generaliy vary due to variation of load conditions during the sunlight period, including peak load events. The requirements of achieving full charge on each orbit is met within this variable charge rate environment by load planning and management as necessary to provide sufficient charge power and time. Completion of recharge is signalled by all charge return coulometry counter and verified by a check of temperature anc voltage responses. This processor-based charge management technique is also used to impose an end-of-charge current taper profile that minimizes rates of oxygen evolution on the nickel electrodes in the cells, thus reducing degradation stresses. 


\section{TRERMAL CONTROL BSBTH}

\section{Qverview}

The PV Module thermal cuntrol syotem (TCS) js an active tysten wilich provides the heat renoval function for all ORi's located on the integrated equipment. assembly; refer to Figure 1. The TCS acquires latit from all ORU's via the ORli baseplate; thermal pad systam discuised previously. The amminis working flidd transports the heat through the IEA to a radiator where se heat is ultinicty rejected to space. A siguificant eftch was expended over the last year to determine the optamum rCs for the PV Module.

\section{Thermal control system study}

The trade study consiated of an analysio and evaluation of a mechanically pumped, two-phase system with a rotating fluid maneigement device (RFMD), vs a pumped, single-phase system patterned after the orbiter single-phase TCS. The background for the two systems includes exterisive analysis and testing underway at Johnson Space Center (JSC) for the two phase TCS and the technology proven in over 25 orbiter flights for the single-phase TCS. work package 02 is developing a $25 \mathrm{~kW}$ two-phase TCS for the space station central thermal control. For the two-phase the Boeing sundstrand system (one of the three candidate two-phase options being evaluated by Work Package 02 , was selected due to its superior performance. The single phase concept is based or tue orbjter Tis d mature techrology with demonstrated Iijght worthiness in over 25 sTs missions.

Either the singie-phase or the two-phase system meets the TCS functional requirements. No exclusion characteristics or "show stoppers" were found for eithe: istem.

A comparison of the functional characteristics of the single- and twophase systems is presented on Table 2. The two-phase system is slightly better in regard to the delta $T s$ or isothermality, but the single-phase system can be designed to approach the same deltas, if required. The single-phase system configuration can provide the same delta $T s$ as the two-phase system, by increasing the coolant flow rate.

Micro-gravity operation is an uncertainty for the two-phase system. A significant amount of development with the attendant development and cost risk to verify operation in the micro-gravity environment of space is required. As planned, Orbiter flight tests will be necessary to verify the two-phase rotating fluid management device (RFMD) system, or any two-phase system. Table 3 present.s a comparison if the trade study results for all criteria evaiuated of note is the fart that smail but signifucant difierences exist for the kE parameters of reliabiljty (MTBF), weight, cost, and maintainability, all favoring the single-phase system. The twophase system has an advantay in pumping power. Most other entries in the tables are equivalent.

Ihe single phase systern was selecteid due to better reliability, better known lechnology and functionality in the micro-g environment, and liwer developme: $t$ risis, also it is somewhat forgiving for high of $f$ normol heat loads. The single-phase system ia simpler than the two phast system ard therefore, has lower maintainability cost on-orbit and lower resupply weight. The single-phase configuration has lower weigtit and lower cost for a system design point in the 3-to 15-kw range. A higher power level system may have favored a two phase system.

\section{SIMGLE PRASE SYSTEM DESCRIPTION}

The FV Module provices cooling for total of 32 orbital replacement units (ORUs) mounted on the utility plates which are ir turn mounted on the IEA. The ORU boxes are about the size of a suitcase ( 28 in. by 38 in.), in which all the batteries; electrical devices and pump packages are instailed. Each oRU has two thermal pads that make contact with the utjlity plate thermisl pads 60 as to conduct the heat. generated by the ORUs to the Acrive TCS coolant channels. The coolant channels are embedded in the utility plates and pass under the thermal pads.

The PV ATCS loop diagram is depicted in Figure 5. Two loops are in the cooling system: one primary and one redundant. Each loop contains its own flow module that includes pump, accumulator, filter, flow control devices, and sensors. The accumulator maintains the coolant pressure at a level suitable for system operation and also serves as a reservoir for additional working fluid. The pump provides pressure head and coolant mass flow rate in the loop. A filter is located at the pump inlet for protection against particulate in the coolant. Working fluid is pumped into the cold-plate coolant channels to absorb the waste heat generated by the ORUs, and then flows through the piping arrangement to transport the waste heat to the radiator panels.

Bypassing the working fluid around the radiators is needed to keep the thermal pad temperature in the specified range for heat loads lower than the design point. The flow proportioning module similar to that used on the space shuttle is utilized for 
the bypass flow control. The coolant is pumped directly into the flow channels within the radiator panels to reject the waste heat to space. The total heat rejected by the radiator is the summation of the heat load and pump heating.

\section{Working Fluid}

Several candidates of working fluid were investigated in order to determine a suitable coolant for use in the singlephase PV ATCS. Because of its high heat capacity and conductivity coupled with low density and viscosity, ammonia $\left(\mathrm{NH}_{3}\right)$ was selected.

\section{Pump Packaces}

The pump package used in the PV ATCS was patterned after a unit from Hamilton Standard used in the orbiter ATCS. Because of the different pressure head requirements between the Orbiter ATCS and the space station PV Module TCS, a single pump instead of four orbiter pumps was chosen. The primary reason for this difference is that the Orbiter ATCS contains a minimum of four compact heat exchangers in series, pump radiators; and longer pipe lines. The recommended single pump provides $3000 \mathrm{lbs} / \mathrm{h}$ of mass flow rate at a pressure rise of 17 psid witn an overall pump efficiency of 258 .

\section{Utifity Plate Thermal Pads}

The thermal pad material is aluminum. The size of the thermal pad is 5 in. by 7 in. Each of the 32 ORU's on the IEA contains two thermal pads. Therefore, the total number of thermal pads is 64. The coolant channels in the thermal pads are multiple pass.

\section{Radiator}

Figure 6 shows the direct-pumped radiator panel concept. The radiator panels are deployed by a scissors-type mechanism. Panel construction is similar to that used on the orbiter.

\section{COHCLUDING REMARKS}

Itis paper discusses the baseline design and development status of the enercy - rage and thermaj control systems trit will be used for space station Freedom's photovoltaic power generation and storage module. At the time of this writing, the Freedom program was considering reducing the amount of power supplied by PV modules while increasing that provided by solar dynamic power modules. Such a change could significantly alter the design and architecture of the energy storage and thermal control systems: these changes, if any, will be discussed in subsequent papers.

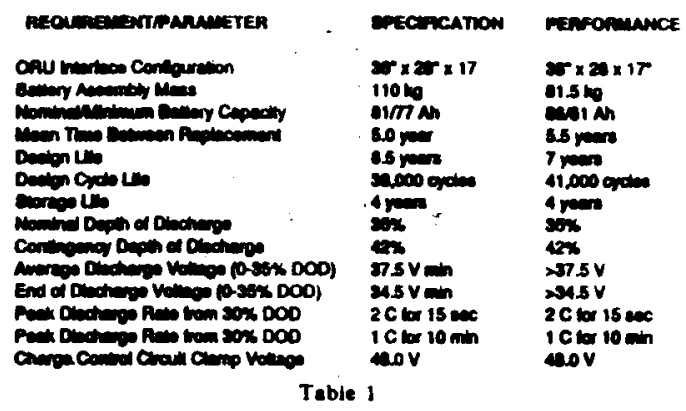

Ballery ORU Performance Projection

\begin{tabular}{|c|c|c|}
\hline Crtierta & $\begin{array}{l}\text { Single-Phace } \\
\text { Direct Radiator }\end{array}$ & $\begin{array}{l}\text { Two Fhase } \\
\text { Hout-Pipe } \\
\text { Radietor }\end{array}$ \\
\hline Powet unaupon & $\begin{array}{l}\text { Only Hemiled by now } \\
\text { milo nod redintios aree }\end{array}$ & $\begin{array}{l}\text { Ooly Hralied by } \\
\text { radiator aroue }\end{array}$ \\
\hline $\begin{array}{l}\text { Operating } \\
\text { nemperioture }\end{array}$ & $-8 \times C$ & $-8^{\circ} \mathrm{C}$ \\
\hline $\begin{array}{l}\text { Toie delle } \\
\text { iompereture }\end{array}$ & $.0 \mathrm{C}$ & $10 \mathrm{C}$ \\
\hline $\begin{array}{l}\text { Otf-bormal } \\
\text { comparature }\end{array}$ & $\mathscr{e q C}^{\circ}$ & ${ }^{10} \mathrm{C}$ \\
\hline Inoibermellity & $\sec$ & $2^{\circ} \mathrm{C}$ \\
\hline Flow & $3000 \mathrm{lb} / \mathrm{h}$ & $70 \mathrm{lt} / \mathrm{h}$ \\
\hline $\begin{array}{l}\text { Ort-normal low } \\
\text { iemperature frezs. }\end{array}$ & $-70 \%$ & $-78^{\circ} \mathrm{C}$ \\
\hline Orbis & Acceplebli & Accepreble \\
\hline$M B$ 1. 2. and 3 & Series $3 \times w$ & Parallel $3 \mathrm{kH}$ \\
\hline ORL repiacemeni & Acceplable & Accepisible \\
\hline inierfaces & Acceplatile $=$ & Accepiatile \\
\hline Zero-l operation & Nol considerstion & ISC to develop \\
\hline Single Failure & Accepisble & Accepiahle \\
\hline $\begin{array}{l}\text { Withelend slorage. } \\
\text { launch, Ironupori, and } \\
\text { environgen! }\end{array}$ & Accepiatie & Accepiable \\
\hline
\end{tabular}

Table 2

Trede Siudy Funeitional Requirmenis consideresions

\begin{tabular}{|c|c|c|c|}
\hline Criterie & $\begin{array}{l}\text { Two-Phase' } \\
\text { Heat-Plpe } \\
\text { Rodiator }\end{array}$ & $\begin{array}{c}\text { Single-Phese } \\
\text { Droct } \\
\text { Redialor }\end{array}$ & \\
\hline Weidens (1 module) & $1,724 \mathrm{db}$ & $1.216 \mathrm{lb}$ & \\
\hline Conl (4 modules) & $229.4 M$ & $325.7 \mathrm{M}$ & \\
\hline Roliebility (MTBF) & $0.026 \mathrm{~b}$ & 9.683 & \\
\hline Devolopmenl Ask & Hith & Low & $\therefore$ \\
\hline Technolosy Rendiness & Semedule Mar & $\begin{array}{l}\text { Mature } \\
\text { Syolem }\end{array}$ & \\
\hline Mow powen (1 module) & $\infty .15 \mathrm{kw}$ & $0.25 \mathrm{kw}$ & \\
\hline EVAIVA (h) & 26.170 & 23.6167 & \\
\hline Mainleinanility/yr & $\begin{array}{l}2.069 \mathrm{lb} \\
310.76 \mathrm{M}\end{array}$ & $\begin{array}{l}1.789 \\
3921 \mathrm{M}\end{array}$ & \\
\hline Flexibility & $\begin{array}{l}\text { Higher } \\
\text { capabilily } \\
\text { inheren1 }\end{array}$ & $\begin{array}{l}\text { Higher } \\
\text { capability } \\
\text { evallatile }\end{array}$ & \\
\hline Commonality & $\begin{array}{l}\text { Radialors and } \\
\text { 'wo-phase } \\
\text { componenis }\end{array}$ & $\begin{array}{l}\text { Ortilter } \\
\text { componenis }\end{array}$ & \\
\hline $\begin{array}{l}\text { Leunct: } \\
\text { pectepting }\end{array}$ & $162 \mathrm{fl}$ & $\begin{array}{l}108 \mathrm{ft}^{\mathrm{3}} \\
\mathrm{cc} \text { bette: }\end{array}$ & \\
\hline
\end{tabular}

Trade Siudy Crilerte Resuli, Compartoon 


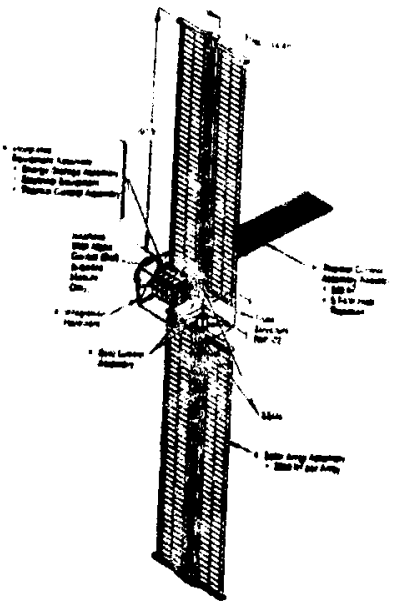

figure 1. Pr nodule
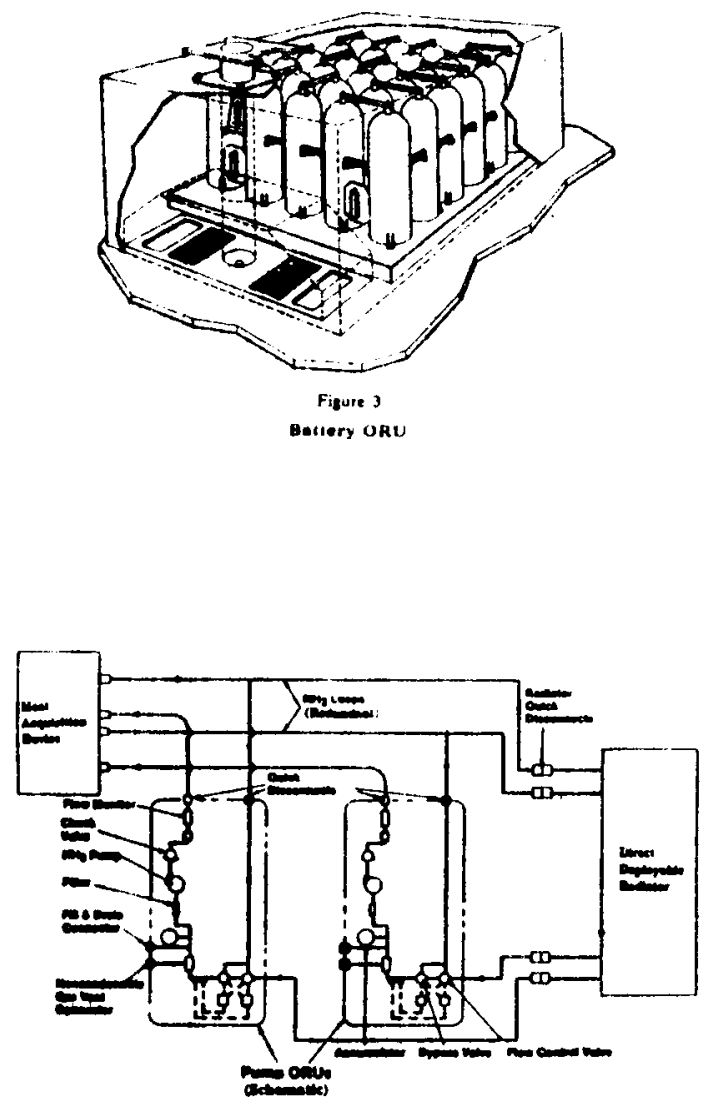

Firoures

SIngle-Phase Direct-Pumped

Redialor Loop Diagram

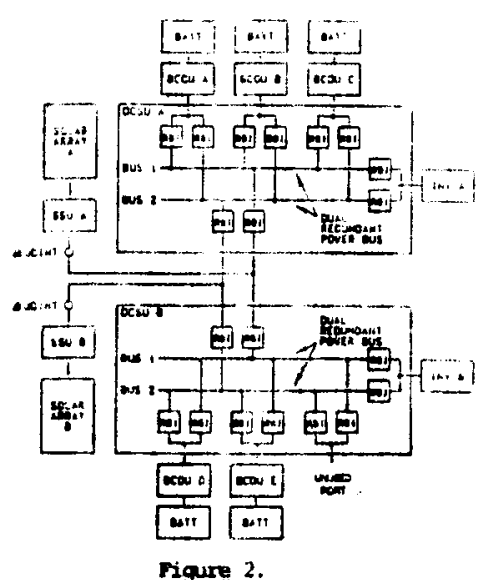

PV fower wodule Subuytem Simple Block Llaur on.

\section{PREDICTEO CYCLE LFE vE. PEHCEMT DOO RELATONEHP}

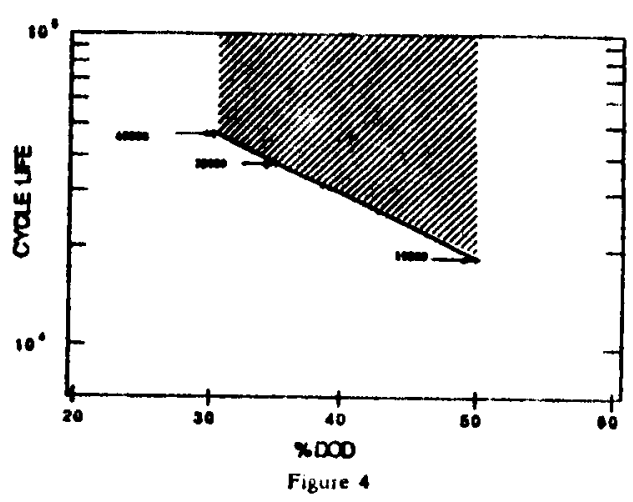

Predicted Cycle I.ire vs.

Percent DOD Relationship
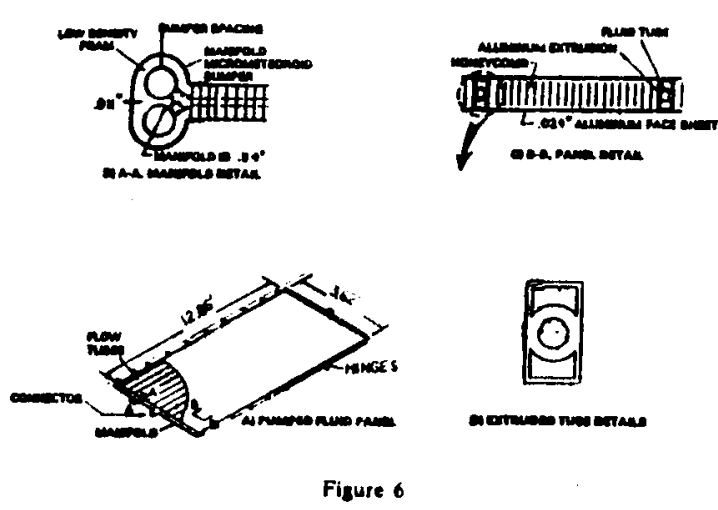

Direci Pumped Redietor Concep1 


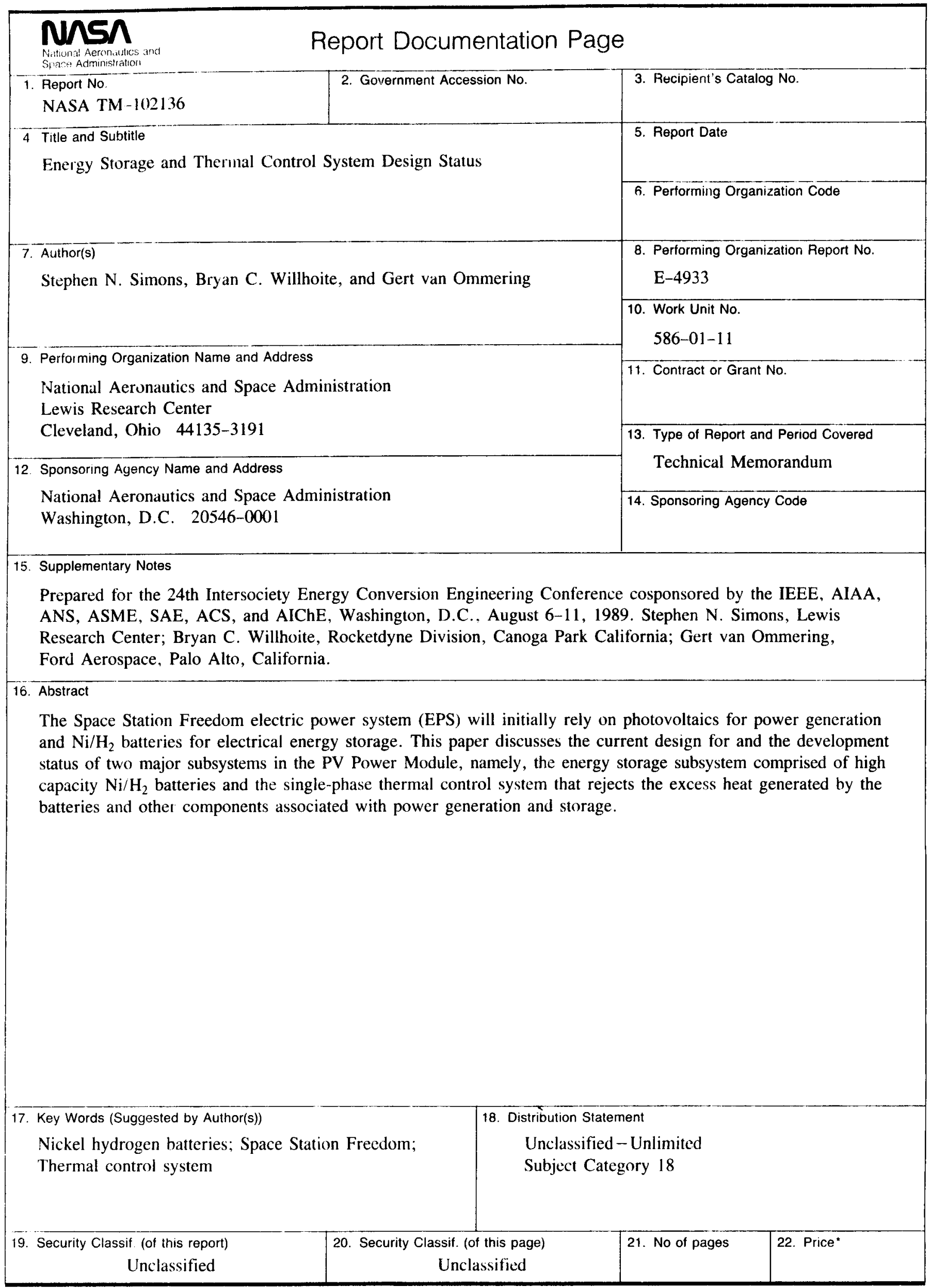

